\title{
CHANGES IN UTERINE AND OVIDUCAL FLUID PROTEINS DURING EARLY PREGNANCY IN THE GOLDEN HAMSTER
}

\author{
I. G. NOSKE* AND J. C. DANIEL, JR \\ Department of Zoology, University of Tennessee, \\ Knoxville, Tenn. 37916, U.S.A.
}

(Received 29th August 1973)

\begin{abstract}
Summary. The total protein concentration was measured in flushings from the hamster reproductive tract during the first 6 days of pregnancy. Protein concentrations reached their highest level in uterine flushings on Day 3 p.c., shortly before the time of implantation.

The protein concentrations in the oviducal fluid fluctuated more than in the uterine fluid, possibly because the oviducal flushings were more prone to serum contamination.

Electrophoretic analysis of uterine and oviducal fluid proteins revealed qualitative and quantitative changes. In both cases, the patterns increasingly resembled those of serum proteins during development. The appearance of a new protein band on Day 3 p.c. was particularly noted. Also of interest was the appearance of a band on Day 4 p.c. in oviducal fluid and the disappearance of one band on Day 5 p.c.
\end{abstract}

Changes of both qualitative and quantitative types have been reported in the uterine and oviducal fluids of a variety of mammals during the cycle and early pregnancy. This communication reports changes in uterine and oviducal fluid protein patterns during early pregnancy in the golden hamster, specifically the appearance of a new protein fraction in hamster uterine fluid shortly before the time of embryo implantation.

Mature female golden hamsters, weighing between 110 and $170 \mathrm{~g}$, were caged in groups of six to eight and observed through two regular cycles (Ward Orsini, 1961), after which they were mated to fertile males. Uterine and oviducal fluids were collected between 17.00 and 18.00 hours from each group of animals on Days 1 to 6 post coitum (p.c.), Day 1 being the day when spermatozoa were found in the vaginal smear. The hamsters were killed by cervical dislocation and uteri and oviducts were blotted dry on filter paper to reduce contamination from other body fluids. Each uterine horn was then flushed with $0.5 \mathrm{ml}$ sterile isotonic saline. The flushings were pooled for each group, centrifuged at 2500 $\mathrm{rev} / \mathrm{min}$ for 5 to $10 \mathrm{~min}$ and concentrated in a dialysis bag placed in granular sucrose.

* Present address: Department of Obstetrics-Gynecology, Roosevelt Hospital, College of Physicians and Surgeons, Columbia University New York, N.Y. 10019, U.S.A. 
Oviducts obtained from the same animals were observed under a stereomicroscope while being flushed with $0.5 \mathrm{ml}$ isotonic sterile saline after insertion of a 27-gauge needle into the infundibulum. Flushings were pooled, centrifuged, and concentrated in the same manner as uterine flushings. Protein concentrations in uterine and oviducal fluid samples were measured by Lowry's method (Lowry, Rosebrough, Farr \& Randall, 1951) using bovine serum albumin (BSA, Sigma) as standard.

The protein-containing fractions of reproductive tract secretions were compared by the ORTEC slab-acrylamide electrophoresis system. For the separation of uterine proteins, a gradient gel was employed, consisting of $6 \%$ polyacrylamide (PAA) layered onto an $8 \%$ gel polymerized together. The well-forming gel was $4.5 \%$ PAA and the gel cap consisted of an $8 \%$ gel. Proteins of oviducal secretions were separated using a 7\% separating gel, a $3.5 \%$ well-forming gel and a $3.5 \%$ cap gel. The electrophoretic run was performed at $325 \mathrm{~V}$, yielding between 50 and $100 \mathrm{~mA}$. The power pulse pattern was 75 pulses/sec $(\mathrm{p} / \mathrm{s}), 150 \mathrm{p} / \mathrm{s}$, and $225 \mathrm{p} / \mathrm{s}$ for $5 \mathrm{~min}$ each, during the initial $15 \mathrm{~min}$, with a final rate of $300 \mathrm{p} / \mathrm{s}$ for approximately $1 \mathrm{hr}$. A borate buffer, $\mathrm{pH} 9 \cdot 0$, was used for separation of uterine fluid, and for oviducal fluid a tris-glycine buffer, pH 8.3, was used in both the lower and upper tanks. Brom-phenol-blue served in both separations as migration indicator. Uterine fluid proteins were stained with Commassie-Blue $\mathbf{R}$ (Sigma). Oviducal proteins were stained with $0.1 \%$ Amido Black (Allied Chemicals) in 10\% acetic acid overnight and then destained in $10 \%$ acetic acid by frequent changes of the solution over 3 days before being photographed.

Table 1 shows the amounts of total protein present during the first 6 days of pregnancy in the golden hamster. The protein concentration on Day 1 was approximately $0.084 \mathrm{mg} / \mathrm{uterus}$ and decreased gradually to $0.055 \mathrm{mg} / \mathrm{uterus}$ on Day 3 p.c. On Day 4 p.c., an increase in protein concentration to about 0.117 $\mathrm{mg} / \mathrm{uterus}$ was observed. Afterwards, it decreased slightly to $0.105 \mathrm{mg} / \mathrm{uterus}$. The total amounts of oviducal fluid proteins are also shown in Table 1 and, as expected, these were lower than those of the uterine proteins. The lowest level was consistently reached on Day 4 when the protein concentration in the uterus was at its highest level. The fluctuations between 0.009 and $0.029 \mathrm{mg}$ protein per oviduct over the 6-day sampling period may have been due to the small size of the oviduct, rendering flushings more likely to be contaminated by serum proteins than those from the uterus.

Plate 1 , Figs $1 \mathrm{~b}$ to $1 \mathrm{~g}$, shows electrophoretic patterns of uterine fluid during Days 1 to 6 p.c. An amount of 98 to $110 \mu$ g protein was separated in each well. A comparison of uterine fluid protein patterns with serum protein patterns (Pl. 1, Fig. 1a) show that hamster serum consists of at least thirteen protein bands and is distinct from uterine fluid. The patterns obtained showed some electrophoretically identical proteins, for example, transferrin and albumin. The most prominent change occurred in the $\alpha$-globulin fraction of uterine fluid where one protein band appeared on Day 3 p.c. that was not detected on the other days of pregnancy when samples were taken. The serum samples showed at least four bands in this same region. There was also an indication of at least two to three bands on Days 4 and 6 p.c., one of which appeared to be 


\section{PLATE I}

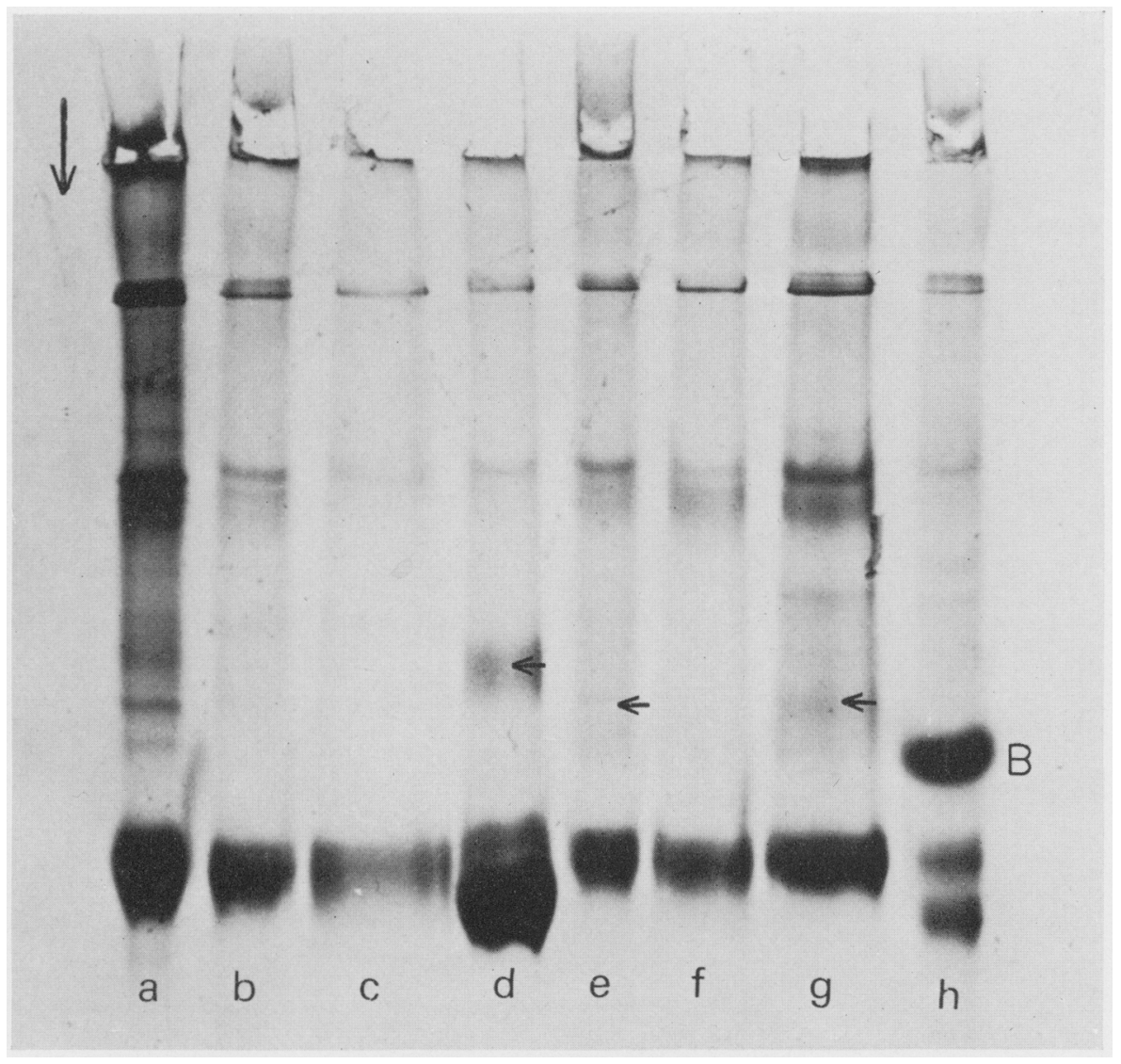

Fic. 1(a). Hamster serum.

Figs 1(b to g). Electrophoretic analysis of uterine fluid during 6 consecutive days of pregnancy in the golden hamster. Arrow indicates the migration direction in the gel. Small arrows show a new protein band on Day 3 p.c.

FIG. 1(h). Rabbit uterine fluid on Day 5 p.c. showing a prominent blastokinin band (B). 
PLATE 2

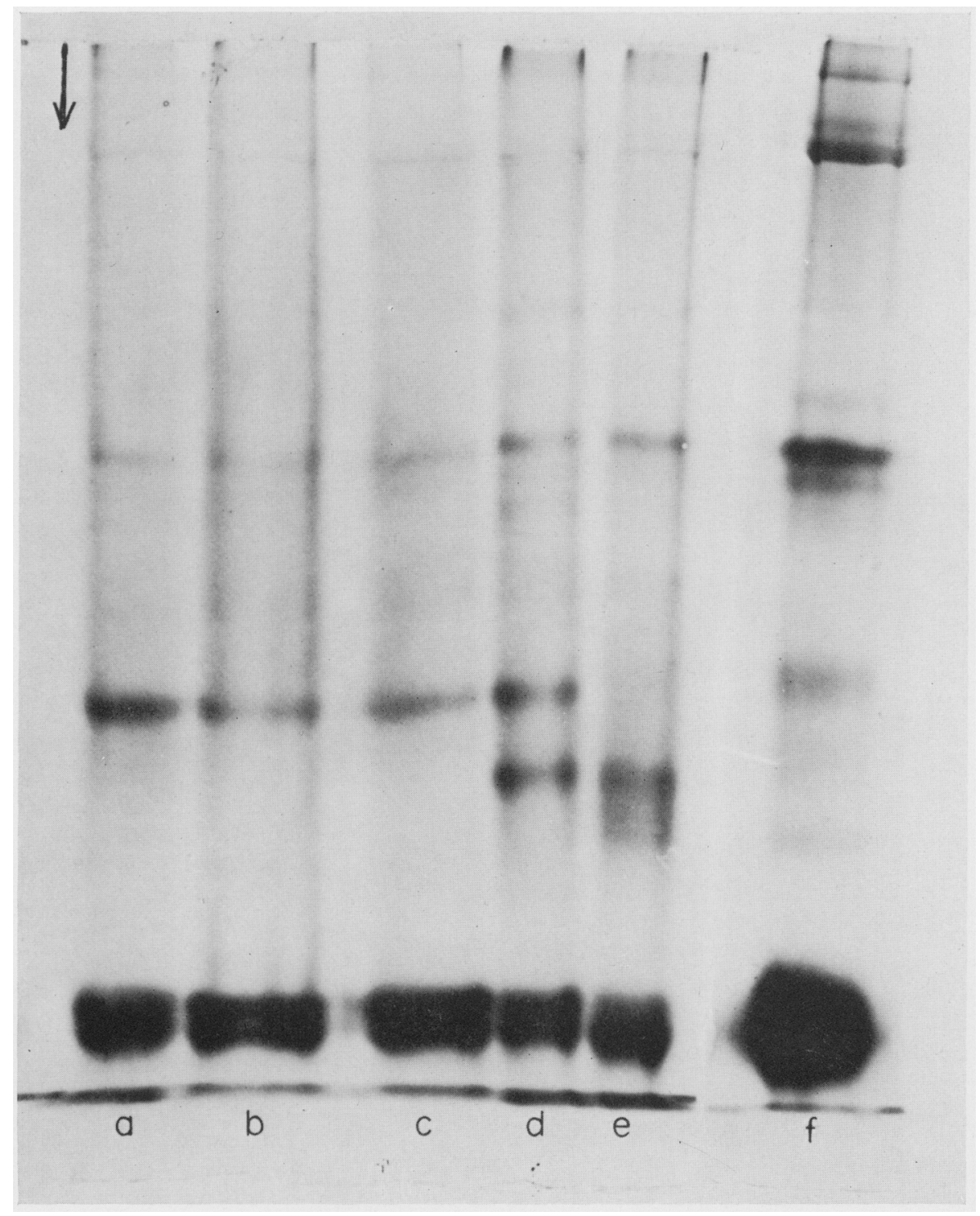

Figs 2(a to e). Electrophoretic analysis of oviducal fluid recovered on Days 1 to 5 p.c. from golden hamsters. The arrow indicates the direction of migration in the gel.

Fig. 2(f). Hamster serum. 
identical with serum (arrow). The $\beta$-globulins consisted of one to two bands on Days 1 to 6 p.c. and the albumin fraction stayed fairly constant during early pregnancy but appeared to separate into two components on Day 3 p.c. (Pl. 1, Fig. 1d). Pre-albumins were seen in some samples taken on Day 3 or later but were hard to demonstrate photographically. The macroglobulin fraction consistently showed two bands that migrated only a short distance from the origin. Plate 1, Fig. 1(h) shows a 5-day p.c. rabbit uterine fluid sample with a prominent blastokinin band (B); obviously, the two hamster bands in the same region did not have the same electrophoretic mobility as blastokinin.

Electrophoretic patterns of oviducal fluid are shown in Pl. 2, Figs 2(a to e). A single band in the macroglobulin and two in the $\beta$-globulin region are seen compared to the two bands and three bands, respectively, which separated in

Table 1. Total protein in uterine and oviducal fluid during early pregnancy in the golden hamster

\begin{tabular}{c|c|c|c}
\hline \multirow{2}{*}{$\begin{array}{c}\text { Days } \\
\text { post coitum }\end{array}$} & \multirow{2}{*}{$\begin{array}{c}\text { No. of animals } \\
\text { examined }\end{array}$} & \multicolumn{2}{|c}{ Total protein } \\
\cline { 4 - 4 } & & mg/uterus \pm S.E. & mg/oviduct \pm S.E. \\
1 & 8 & $0.084 \pm 0.036$ & $0.027 \pm 0.007$ \\
2 & 9 & $0.069 \pm 0.034$ & $0.018 \pm 0.009$ \\
3 & 19 & $0.055 \pm 0.031$ & $0.029 \pm 0.003$ \\
4 & 13 & $0.117 \pm 0.046$ & $0.009 \pm 0.007$ \\
5 & 18 & $0.110 \pm 0.048$ & $0.017 \pm 0.002$ \\
6 & 6 & $0.105 \pm 0.035$ & $0.025 \pm 0.006$ \\
\hline
\end{tabular}

serum (Pl. 2, Fig. 2f). The $\alpha$-globulin region showed a single band during the first 3 days; thereafter, an additional band appeared which migrated faster in the gel. On Day 5 p.c. of the sampling period, the first band vanished, and another faster migrating band could be observed. The presence of two bands in the $\beta$-globulin region during early pregnancy in the hamster is interesting having regard to the appearance of a protein band in the same region in postovulatory monkey oviducal fluid (Mastroianni, Urzua \& Stambaugh, 1970).

These changes in hamster uterine fluid proteins, like those reported in the rabbit (Krishnan \& Daniel, 1967; Beier, 1968; Hamana \& Hafez, 1970; Gulyas \& Krishnan, 1971; El-Banna \& Daniel, 1972), coincide primarily with the period of blastocyst cavitation (Ward, 1948; Krishnan \& Daniel, 1967). There is tendency for the protein components increasingly to resemble those in hamster serum (PI. 1, Fig. la) as pregnancy advances. This seems to indicate a selection of serum proteins into the reproductive tract during early pregnancy.

The timing of these changes also coincides with changes in circulating progesterone levels (Leavitt \& Blaha, 1970) and we suggest that, as has been shown in the rabbit (Arthur \& Daniel, 1972; J. C. Daniel \& P. A. Murray, unpublished work), proteins during early pregnancy are dependent on the increasing level of this steroid. Experiments on ovariectomized hamsters subsequently treated with hormones as well as protein patterns during the oestrous cycle (Noske, 1972) have shown that the production of uterine proteins is under the regulation of oestrogens and progestins. 
This work was supported by NIH Grant USPHS-HD-06226-01.

\section{REFERENGES}

Arthur, A. T. \& Daniel, J. G., JR (1972) Progesterone regulation of blastokinin production and maintenance of rabbit blastocysts transferred into uteri of castrate recipients. Fert. Steril. 23, 115.

Beier, H. M. (1968) Uteroglobin: A hormone-sensitive endometrial protein involved in blastocyst development. Biochim. biophys. Acta, 160, 289.

El-BanNa, A. A. \& Daniel, J. G., JR (1972) The effect of protein fractions from rabbit uterine fluids on embryo growth and uptake of nucleic acid and protein precursors. Fert. Steril. 23, 105.

Gulyas, B. J. \& Krishnan, R. S. (1971) Current status of the chemistry and biology of "Blastokinin". In The Biology of the Blastocyst, p. 262. Ed. R. J. Blandau. University of Chicago Press.

Hamana, K. \& Hafez, E. S. E. (1970) Disc electrophoretic patterns of uteroglobin and serum proteins in rabbit blastocoelic fluid. 7. Reprod. Fert. 21, 555.

KRIShNAN, R. S. \& Daniel, J. G., JR (1967) "Blastokinin": inducer and regulator of blastocyst development in the rabbit uterus. Science, N.Y. 158, 490.

LeavitT, W. W. \& BlaHA, G. C. (1970) Circulating progesterone levels in the golden hamster during the estrous cycle, pregnancy and lactation. Biol. Reprod. 3, 353.

Lowry, O. H., Rosebrough, N. J., Farr, A. L. \& Randall, R. J. (1951) Protein measurement with the Folin phenol reagent. F. biol. Chem. 193, 265.

Mastrotann, L., JR, Urzua, M. \& Stambaugh, R. (1970) Protein patterns in monkey oviducal fluid before and after ovulation. Fert. Steril. 21, 817.

NoskE, I. G. (1972) Hormonal control of uterine fluid protein patterns and sperm capacitating ability in the golden hamster. Am. Zool. 12, 705, Abstr.

WARD, M. G. (1948) The early development and implantation of the golden hamster, Mesocricetus auratus, and the associated endometrial changes. Am. F. Anat. 82, 231.

WARD ORsini, M. (1961) The external vaginal phenomena characterizing the stages of the estrous cycle, pregnancy, pseudopregnancy, lactation, and the anestrous hamster, Mesocricetus auratus Waterhouse. Proc. Anim. Care Panel, 11, 193. 